\title{
When you become the lived experience: The journey backwards from academia
}

\author{
Mim Fox ${ }^{1}$ and Sarah Wayland ${ }^{2}$
}

\begin{abstract}
1 University of Wollongong, Australia

2 University of Sydney, Australia
\end{abstract}

\begin{abstract}
The transition from lived experience to social work researcher or teacher is well known and, in many ways, an expected pathway. What is less documented is the lived experience that happens to the social work researcher or teacher, the moment the researcher becomes the research topic, or the teacher becomes the lesson. In writing these reflections we, the authors, have reflected on, and engaged with, our experience as researchers and academics who know and understand grief from a distance. We have previously positioned ourselves as experts and, through lived experience, have come to a place of not knowing. From there we have stumbled awkwardly on to new understandings, hopefully to enrich our future research and teaching.
\end{abstract}

KEYWORDS: Academia; narrative; reflection; grief; social work
AOTEAROA

NEW ZEALAND SOCIAL WORK 32(2), 32-36.

CORRESPONDENCE TO: Mim Fox

mfox@uow.edu.au
Within social work literature, much time is given to the notion of lived experience and its negating or its heralding. Much of this polarity is brought about by thinking about the impact that lived experience has on notions such as professionalism, boundary setting and implicit positions of power. As a profession and as a source of academic scholarship, social work has enforced understandings of these notions through practice-based critical reflection (Yip, 2006), through professional structures such as clinical supervision (Egan, 2012), and through a formative understanding of reflexivity (Watts, 2019). Throughout all of this, the positioning of the expert is a moveable feast and the place of lived experience in the literature, ill defined. Given this context we, the authors, have queried our own positionality as academic experts, having established ourselves in academia and later experienced the previously objective phenomenon we have studied, as subjective.

\section{Researching our lived experience}

The phenomenological and narrative approach, and self-study as a form of autobiographical research, has been used to examine the lived experience of female academics (Kudarauskienė \& Žydžiūnaitè, 2018), to access issues inherent within academia (Mellifont et al., 2019) and more specifically in the lived experience within academic education and practice teaching (Uusimaki \& Garvis, 2017). When producing a narrative about lived experience in academia, the question is posed as to whether the absence of such narratives negates the worthiness of the lived experience (Toepell, 2003). By producing a reflexive understanding of ourselves in our writing (Behl, 2019) we are establishing ourselves as dominating our narrative through both "gifted storytelling" (Terare \& Rawsthorne, 2020, p. 956) and a professional sense of social work practice wisdom and collective understanding (Weick, 2000). 
We both started our careers in social work practice and, through the presented narratives, we are able to track our beginnings into research, teaching and academia. Themes that emerge in both our narratives are a combination of lived experience mixed with intellectual curiosity, an element of self-discovery as a practitioner and educator, and a realisation of the distance between intellectual "knowing" and a deep awareness of "being". Hunter (2010) tells us that qualitative researchers approach their work dependent on "the context of the teller and the listener" (p. 44), ensuring that we acknowledge that more than one truth about a person's lived experience, can be discovered. The shift between knowing of lived experience, to living the experience requires a level of reflective practice not commonly discussed in academia. Both of us have spent our careers "knowing" grief and its many permutations. Through writing and reflecting on the following narratives we have been able to question the place of "knowing" in academia and scholarship and the less tangible, but equally vital, place of "being".

\section{Mim's story:}

A few years after I started practising as a social worker my close friend's mother died of cancer. My friend flew back home to take care of her dying mother in her last months. They had set up a medical bed in the lounge room where she could be surrounded by her favourite paintings and colours, where the sun in her beachside home would settle in on her. I remember feeling useless as I sat with my friend, feeling lost for words. When her mother died, I remember not wanting to feel so useless to the people that I loved again and so I started looking for work in the hospital system, drawn to the place where most people go to die. Nearly 20 years later I had practised largely in the hospital system, working with people as they died slowly of chronic conditions and quickly of traumatic and untimely deaths. Over the years I sat with people next to their beds in wards and in their homes. I visited dying people in nursing homes, and I developed a morbid fascination with mortuaries and funeral parlours, and how we care for our dead. Whilst practising as a social worker and later working as an academic who teaches social work students, I would often teach grief and loss theory, bereavement support and focus on micro skills such as sitting in silence, having brave and difficult conversations, how to demonstrate empathy without saying a word. I entered into research partnerships with my hospital colleagues and would often feel drawn to the research questions and discussions about my old haunts, the intensive care units and emergency departments, the chronic and complex wards. The places in hospitals that death inhabits. I thought I understood what it meant to care for a dying loved one but, more so, I thought I understood how to teach to it and how to research it.

Then my father died. He died slowly but also quickly. He suffered from Parkinson's disease for 12 years while my mother cared for him at home. He was admitted into an acute hospital ward, transferred from there to a rehabilitation hospital, and from there to a nursing home to die. From his admission to his death it was a total of 10 weeks and I did what I knew how to do. I sat with him and my mother and my siblings. And through that I realised that I only knew a fraction of what I taught and researched. So, for 10 weeks I thought about what it was that my social work students needed to know.

I saw my father move from speaking and laughing and making jokes with the nurses to being unable to speak at all, to only be able to cry out in pain and then not even that. I thought about how my students needed to understand the fragility of life, that when they meet a person at end stage, they are meeting a fraction of the person that was. As I watched my mother move from being a primary carer to being a distraught life partner I thought about how my students needed to understand the impact of caring for another person that you have committed your life to, and what that feels like to watch them die. I realised that when we teach about what it means to be a carer in social work education, we often teach about what carers need for support rather than teach about the emotional impact of their loss.

As I sat by my father's bedside, I saw the nurses change as the weeks went on. I noticed how, 
as he became weaker, they became slower in how they spoke to us, halting and hesitant in their approach. I noticed that they had begun giving half-smiles as they passed the open door, sending sympathy into my father's room. I realised I needed to teach my students what the environment tells you about the experience of the people within it, that an environment has the potential to cushion and enfold emotion whilst also alienating those within it.

In my father's last days, I watched as the nurses, one by one, came to us and told us their own stories of loss. One nurse had sat by her child's bedside as they struggled in hospital. One nurse had lost his father and still became teary talking about it 12 years later. And on the night my father died, one nurse told us that she had not been able to be with her father as he died as he was on the other side of the world, and that we were lucky to be there with ours. I realised that my students needed to understand that community comes in various guises. That you can never know who will emerge as your greatest supports and that ticking a box called "supports" on an assessment form can never adequately answer that question.

Three months later, I started teaching a social work practice in healthcare subject and as I introduced the subject to my social work students, I heard myself say, "This is not a subject about other people. This is a subject about us. About how we live and die, how we care for each other, and how we wrestle with our life experience".

\section{Sarah's story:}

In my last conversation with my ex-husband, exactly nine days before he died, I asked him where he thought he was going when he died. There had been a lull in our conversation. I'd walked into the hospital room, after my daughter asked me to see him first as she hid herself in the tiny room outside his. I was to come back and report what I'd seen, how he had looked. I hadn't seen him for more than a year, since he had been newly diagnosed with Stage 4 lung cancer. At the hospital that day, he considered my question. He put his hand to his head and rubbed it, he told me he was going nowhere. That he wasn't religious and that, when he died, "that was it". The spiritual brutalness of his words, were followed by him folding his arms - his way of saying the conversation was over. His answer didn't compute in my grief researcher brain. I hadn't anticipated there could be people who didn't sit or dwell on theories about the meaning of life and death, who hadn't explored on some level their physical life versus their spiritual one. I couldn't find a chapter in any of the books I had often re-read, about people like him. The ones that approached death with stoic avoidance. There was no meaning-making when the meaning wasn't there to hold on to. He was a qualitative researcher's nightmare.

I am a grief researcher, I've spent 16 years working with families of missing people, exploring their loss that is defined as ambiguous or unresolved. Many health researchers, like those who look at grief, or trauma or mental health, often come to their topic because of a lived experience, or exposure to an event that triggers interest and warrants further exploration. Last year I became the proverbial cart before my horse, my lived experience of a disenfranchised grief happened after my research niche was developed. In the first weeks after he died in April 2019, I started to write as a way of showing up and honouring the trauma that his death created. My own background as a social worker and a grief researcher didn't prepare me for how I would react. I felt robbed in a way that all this hard work gaining a PhD, where suddenly every narrative I'd ever analysed did little to help me in my own grief. I couldn't identify how one in every two marriages ended in divorce yet, so little is discussed about grief when one of those partners dies. I knew I wasn't alone, but I couldn't locate others like me. It would be silly to suggest that this unique type of intangible loss is not uncommon. It's a symptom of a society where relationships are often fragmented, and families are not always connected in life and then in death. Grief, we are often told in every social media meme, is a reflection of love. So, where does this leave us if love is absent but grief is present?

My ex-husband had been in my life for the last 20 years, the relationship had been strained but 
persistent. We were disconnected yet enmeshed. We had been pulled in by him at the time of death yet held at arm's length as he slipped away. What I know is, if grief reactions exist after that first year, in a way that impact the capacity to live with day to day life, then (given I have a whole career's worth of grief experience) we understand it to be potentially labelled as prolonged grief disorder. But grief isn't a disorder when we live with it. It becomes part of the way we look at the world, the sadness and disengagement in each sigh, and the bags under your eyes after nights of lying awake trying to work out what all "this" means. You see, when a person is no longer the next of kin, a death can create or trigger feelings of powerlessness. It can remove the chance to enact rituals that commonly assist people to mourn the loss of a person - both physically and psychologically. There is no funeral preparation, there is no chance to be heard. Coming to my research, from a lived experience perspective after $I^{\prime} d$ spent so long living in it, meant I had to locate myself amidst the trauma of my own ambiguous loss. That the silencing of my loss, by those around me, and in the activities that come from death, created little opportunity to understand why I was in so much pain after his death. The pain I felt was embarrassing, I held up a mirror to my emotions and realised that no one saw the same reflection I did. The definition of lived experience seeks out opportunities for people to share their unique life learnings about surviving, I reached out to my social media community a month after his death. Publishing under my academic title, blending the professional with the personal. Reminding others that we cannot distance ourselves from the research we do, if we are encouraging open reflective practice from those who see us in the counselling space or agree to take part in our research. That we are all in this together-the messy grief of life.

\section{Conclusion}

The journey of lived experience to practitioner, teacher or researcher is anecdotally well known. However, the opposite experience, that of practitioner, teacher or researcher is not only underdocumented but is little discussed. The effect, however, on the practitioner, teacher or researcher of meeting and experiencing their "known" phenomenon is nonetheless profound. Through presenting our narratives we aim to contribute to the understanding of the development of the notion of the social work academic as expert, and of the lived experience as an othering notion. We believe social work is a profession about life and to negate our own lived experience is to negate our ways of knowing and being. We understand the imperative to engage with your subject matter as a process of living, bringing the boundaries between the lived experience, the classroom and academia that much closer.

Accepted 15 June 2020

Published 1 August 2020

\section{References}

Behl, N. (2019). Mapping movements and motivations: An autoethonographic analysis of racial, gendered, and epistemic violence in academia. Feminist Formations, 31(1), 85-102. http://doi.org/10.1353/ff.2019.0010

Egan, R. (2012). Australian social work supervision practice in 2007. Australian Social Work, 65(2), 171-184. https://doi-org.ezproxy.uow.edu. au/10.1080/0312407X.2011.653575

Hunter, S. V. (2010). Analysing and representing narrative data: The long and winding road Current Narratives, 2, 44-54. https://ro.uow.edu.au/currentnarratives/vol1/ iss $2 / 5$

Kudarauskienè, A., \& Žydžiūnaitnè, V. (2018). Feeling guilty by being in-between family and work: The lived experience of female academics. Indo-Pacific Journal of Phenomenology, 18(2), 1-10. https://doi.org/10.1080/20 797222.2018.1500670

Mellifont, D., Smith-Merry, J., Dickinson, H., Llewellyn, G., Clifton, S., Ragen, J., Raffaele, M., \& Williamson, P. (2019). The ableism elephant in the academy: A study examining academia as informed by Australian scholars with lived experience, Disability \& Society, 34(7-8), 1180-1199. https://doi-org.ezproxy.uow.edu.au/10.1080/ 09687599.2019.1602510

Terare, M., \& Rawsthorne, M. (2020). Country is yarning to me: Worldview, health and well-being amongst Australian First Nations people. British Journal of Social Work, 50(3), 944-960. https://doi-org.ezproxy.uow.edu. $\mathrm{au} / 10.1093 / \mathrm{bjsw} / \mathrm{bcz072}$

Toepell, A. R. (2003). Academic mothers and their experiences navigating the academy, Journal of the Association for Research on Mothering, 5(2), 35-46.

Uusimaki, L., \& Garvis, S. (2017). Travelling academics: The lived experience of academics moving across countries. Higher Education Research \& Development, 36(1), 187-200. https://doi-org.ezproxy.uow.edu.au/10.1080/07 294360.2016.1178217 
Watts, L. (2019). Reflective practice, reflexivity, and critical reflection in social work education in Australia. Australian Social Work, 72(1), 8-20. https://doi-org.ezproxy.uow. edu.au/10.1080/0312407X.2018.1521856

Weike, A. (2000). Hidden voices. Social Work, 45(5), 395-402. https://doi-org.ezproxy.uow.edu.au/10.1093/ $\mathrm{sw} / 45.5 .395$

Yip, K. (2006). Self-reflection in reflective practice: A note of caution. British Journal of Social Work, 36(5), 777-788. https://doi-org.ezproxy.uow.edu.au/10.1093/bjsw/bch323 